\title{
7
}

\section{Assessing China's Trilateral Aid Cooperation and Foreign Aid Reform}

This chapter builds on the analysis in previous chapters and continues the discussion on China's trilateral aid cooperation. It will provide an overview of Chinese trilateral aid cooperation, including development partnerships, prominent features, China's official position and bureaucratic arrangement for trilateral aid cooperation. Trilateral aid cooperation, especially in China's cases, will then be assessed. The chapter will also examine China's foreign aid reform, of which trilateral aid cooperation is a manifestation, and the establishment of the CIDCA in 2018.

\section{Overview of China's Trilateral Aid Cooperation}

\section{Development Partnerships}

This research has revolved around China's motivations for trilateral aid cooperation. It concludes that China's adoption of trilateral aid cooperation is the result of its strong desire to build its global image as a responsible global power and for cognitive learning to improve its aid performance. This finding is based on the careful examination of China's three trilateral projects in Chapters 4, 5 and 6, as well as an understanding of China's other trilateral projects. 
With regard to cognitive learning, we must emphasise once again that a large proportion of China's learning has been derived from the process of its acceptance of aid from traditional donors and multilateral development agencies. This process not only made Chinese actors believe that external aid could be beneficial to China's economic development, but also that the process increased their understanding of and trust in these partners, which contributed to the confidence of Chinese actors in undertaking trilateral aid cooperation.

Following the logic that Chinese actors are keen to improve China's global image and to promote cognitive learning, why have traditional donor states and multilateral agencies rather than China taken the lead in initiating the pilot projects? As demonstrated in previous chapters, traditional donor states and multilateral agencies have increased their interests in Chinese foreign aid in the last decade, especially after China pledged extensive amounts of aid to Africa at the 2006 summit of the forum on ChinaAfrica cooperation in Beijing. In response to the anticipated significant expansion of China's aid, these players began to approach China and increase their engagement. In turn, the Chinese government agreed to become more involved in these kinds of engagements. Chinese officials believed that participating in trilateral proposals that were initiated by external partners could serve China's interests, including internationally projecting a cooperative image and facilitating China's practical learning from traditional donors. That is why China agreed to tentatively experiment with trilateral aid cooperation but refrained from being more proactive. China's reactive position is also related to its tradition of risk aversion when dealing with new approaches, such as trilateral aid cooperation. This is complicated by the Chinese government's doubts, as well as those of many of its agencies, regarding the motivations of external partners, especially traditional donor states, pursuing trilateral cooperation agreements with China, particularly in the early stage of engagement. That is also why China was more willing to test trilateral cooperation with UN agencies such as the UNDP, as it is considered by the Chinese government to be politically more neutral than Western donors.

China's strategic approach towards learning in the aid sector has demonstrated similar features to its practices in other fields of international affairs, such as arms control. As mentioned in Chapter 2, Ernst Haas (1990, pp. 3-4) explained two types of learning processes: adaptation and learning. Adaptation signifies the use of new means to achieve the same goal, while learning signifies the change of both goals and means on the 
basis of redefining actors' interests. Alastair Iain Johnston (1996) used these two concepts to analyse China's development of a more sophisticated and constructive arms control policy in the 1980s and 1990s. He argued that this was a process of adaptation-changing the means of engagement while avoiding a paradigm shift in China's realpolitik arms control policy — rather than a process of learning — a paradigm shift that would involve changes in China's basic assumptions regarding both the goals and means of arms control policy. My research has reached similar conclusions. China's growing enthusiasm for aid cooperation and engagement with traditional donors has been a process of adaptation. China's perception of cooperation with traditional donors has changed greatly since the 1970s - from allowing foreign aid to enter China, to piloting trilateral aid cooperation with traditional donors in Third World countries. China has mainly aimed to build its global image as a responsible global partner and to learn some useful aid practices from traditional donors to fill its own gap. This kind of learning has been selective and focuses on areas that are deemed suitable by the Chinese government. There is no change to China's aid paradigm, no shift in the goals and means of its aid program. China's basic perception of its aid as part of south-south cooperation has remained unchanged since the 1950s.

The extent to which international aid regimes independently influence China, including its adaptation of trilateral aid cooperation, also deserves attention. Again, Johnston has examined the influence of international institutions on China between 1980 and 2000, especially in the arms control sector. He argued that international institutions have played three roles in different settings: 1) mimicking-China as a novice in international affairs initially copied the behavioural norms of other states; 2) social influence-China's behaviour as a novice is judged by these states, as well as rewarded/punished; and 3) persuasion-China is encouraged to accept particular norms and values of the institutions (Johnston, 2007).

In the case of China's aid, as previous analysis has demonstrated, the traditional aid regime and its members-whether traditional donor states or international development agencies-have tried to integrate China into the international aid system and have encouraged China's adoption of their aid norms and practices. Their efforts have yielded some results, as China agreed to accept aid from these partners from the late 1970s and has expanded its development engagement and cooperation. Elements of mimicking, social influence and persuasion could be detected in the process of the engagement between China and traditional donor states 
and international development agencies. For example, a common goal of the US, Australia and the UNDP in the exemplary trilateral aid projects in Chapters 4-6 was to encourage China to learn from its aid practices, if not explicitly to shape China's aid practices. However, international engagement in itself would not have worked if China had not placed more emphasis on global image-building in its diplomacy, including aid delivery, because China could turn a blind eye to engagement efforts from traditional donors. Moreover, China's international engagement has been a reciprocal process. While traditional donor states and international organisations have tried to influence China, China has worked to consolidate some of its own rules in cooperation. For example, to reduce the risk of being regarded as getting closer to traditional donors and weakening its status as a south-south cooperation partner, China has insisted that trilateral aid cooperation be supported and preferably initiated by the developing countries. This 'condition' has been accepted by traditional donor states and international organisations in China's pilot trilateral projects.

There have also been finer distinctions for China's image building across diverse settings, whether in the development sector or beyond. China has placed increasing efforts on global image-building since the 2000s; however, its objectives vary with different development partners and different regions. To traditional donor states and international organisations who have taken the lead in engaging with China, China has aimed to project a benign image as a responsible stakeholder and a trustworthy development partner in response to their call for more coordination and cooperation. As the case of China-US trilateral cooperation has shown, China expects to build an image as a responsible stakeholder to serve the broader China-US relations. In contrast, as many developing countries face the growing challenge of aid coordination among donors, China has attempted to use trilateral aid cooperation to support the aid coordination between China and traditional donors in these recipient countries, which will improve China's image.

Further, China's motivations for global image-building in its broader diplomacy are not uniform. In Africa, China seeks to shrug off its negative neo-imperialist image-which is crucial, as China has kept emphasising its common identity with African countries as former colonies of Western powers. In Asia-China's immediate neighbourhood of intractable territorial disputes_image building in China's broad diplomacy is seemingly more about reassurance, especially in light of China's image 
as an assertive actor in the maritime realm and the perceptions of its neo-mercantilist approach towards commercial investment. For Pacific Island countries who are not a focus of China's diplomacy and economic outreach and who do not have territorial disputes with China, China's image building has focused on projecting the image of a good southsouth cooperation partner. However, this distinction of global imagebuilding in China's broad diplomacy is not that clear in relation to the specific concern of trilateral aid cooperation. This question deserves more investigation in the future, as China is currently still in the early stage of piloting trilateral aid cooperation in these regions. At this stage, it appears that China has aimed to use trilateral aid cooperation to improve aid coordination in recipient countries.

China's global image-building and cognitive learning vary in different settings. China has a nearly four-decade-long engagement with Australia and the UNDP regarding development cooperation, which has facilitated China's learning from the two partners. However, because China only began aid engagement with the US in 1999, China's learning of aid management from the US is limited. In this case, China's motive to build its image as a responsible stakeholder in the eyes of the US serves its broader bilateral relations.

Before concluding this subsection, it would be useful to briefly examine the case of Samoa. This would have been a most likely case for trilateral cooperation to occur, but it failed to eventuate, which confirms my findings. Among the Pacific Island countries, Samoa has performed well in managing aid effectively and promoting aid coordination among donors (Smith et al., 2014, pp. 18-19; Interview with Assistant Chief Executive of Samoa’s Ministry of Finance Peseta Noumea, Apia, 26 February 2015). Due to this, Samoa has been running training sessions for aid officials from its Pacific neighbours, such as PNG, on how to promote aid coordination (Interview with Peseta Noumea, Apia, 26 February 2015). Samoa was also among the earliest Pacific Island countries to establish diplomatic relations with China. ${ }^{1}$ This relationship has been recently lauded by China's Premier Li Keqiang, who in November 2015 referred to Samoa as 'a model of the relations between China and the Pacific island countries' (Chinese Embassy in Samoa, 2015, para. 8).

1 Fiji established diplomatic relations with China on 5 November 1975, and Samoa did so the following day. 
Despite these favourable conditions, China is yet to initiate a trilateral aid project in Samoa. In this respect, Samoa lags behind the Cook Islands and PNG, who are already conducting trilateral aid cooperation with China on their own soil. Based on my research, the main reason for this is that it is currently the traditional donor states and multilateral development agencies, rather than the recipient countries or China, who have taken the lead in proposing trilateral projects. Although the Chinese government has agreed to pilot these new partnerships, its behaviour is mostly reactive rather than proactive. In the case of Samoa, there is little push from traditional donors for trilateral cooperation with China. Australia has historically focused its aid programs on the Melanesian countries, especially PNG, rather than on Samoa. Australia and China are also preoccupied with their trilateral project on malaria control in PNG and cannot expand this modality to other recipient countries (Interview with a senior Australian aid official, Port Moresby, 4 November 2014). Although Samoa is a top recipient of New Zealand's aid in the Pacific, New Zealand has made it clear that it will be concentrating on the pilot trilateral water supply project in the Cook Islands before extending trilateral partnerships to other recipient countries (Interview with David Nicholson, Wellington, 12 December 2014). ${ }^{2}$

\section{Prominent Features}

China has participated in a growing number of trilateral aid projects in recent years, as elaborated in Table 1. Close observation reveals some distinguishing features. First, these projects tend to be small in aid volume. Aside from the $\$ 53.2$ million $^{3}$ China-New Zealand-Cook Islands trilateral project on water supply (Mabbitt, Hamilton, Raffe, Eggleton \& Huttche, 2015, p. 23), ${ }^{4}$ funding for Chinese trilateral projects is extremely modest. For example, the China-Australia-PNG trilateral project on malaria control has a budget of only AU $\$ 4$ million. Second, the projects are technical in nature and focus on less sensitive areas, such

2 David Nicholson, director of Pacific development division, New Zealand Ministry of Foreign Affairs and Trade.

3 The estimated cost of the project is NZ\$66.3 million, equivalent to US\$53.2 million based on the exchange rate in August 2012, when the project agreement was signed. China Exim Bank agreed to provide US\$18 million (RMB 117 million).

4 Although the governments of China and New Zealand highlight this project as trilateral, some analysts argued that this is not a trilateral project, but two bilateral projects in parallel. China built the main ring of the water supply while New Zealand is responsible for other issues, including connecting the main ring to the households. 
as agriculture and food security, public health, disaster risk management and technical training. They do not cover politically sensitive issues like good governance, anti-corruption or human rights. The China-AustraliaCambodia trilateral irrigation dialogue (November 2013 - June 2014) is also categorised by China and Australia as a trilateral project.

China also has different policies for cooperating with traditional donor states and UN agencies on funding contributions. The Chinese government insists that traditional donor states provide funding in trilateral projects, while China contributes only technical expertise. China believes that this position is justified because it is still a developing country compared to traditional donors. Although China made financial contributions to its trilateral water supply project with New Zealand in the Cook Islands, this is an exceptional case because the China Exim Bank and the Chinese project contractor CCECC were eager to materialise a concessional loan agreement that was signed with the Cook Islands government before its expiry (Interview with Cook Islands Finance Minister Mark Brown, Apia, 27 February 2015). In contrast to its trilateral partnership with traditional donor states, China has funded some trilateral projects with UN agencies. To the Chinese government, China is a member of these organisations, and providing funding to UN agencies is not inconsistent with China's identity as a developing nation. Additionally, working with the UN could potentially lift China's global image as a responsible member state of the international community. Consequently, China financed the two phases of the China-UNDP-Cambodia trilateral aid project on cassava with $\$ 610,000$ in total. Together with the UNDP, China has also approved an allocation of $\$ 500,000$ for the trilateral project on disaster risk management in Malawi.

Building on the pilot projects, China is moving further towards testing different forms of trilateral cooperation. Similarly, it has started with the UNDP again due to their trust building over the past four decades. A UNDP official categorised the development of China-UNDP trilateral aid cooperation into three generations. ${ }^{5}$ The first generation refers to projects that are conducted with pooled resources, especially joint funding from China and the UNDP in a Third World country. China and the UNDP identify a potential project for cooperation, which will combine China's expertise with international best practices from the UNDP.

5 Author's interview (Beijing, 30 July 2015). The rest of the paragraph is paraphrased, based on the remarks of this UNDP official. 
The China-UNDP-Cambodia trilateral project on cassava, ${ }^{6}$ the ChinaUNDP-Burundi trilateral project on renewable energy and the ChinaUNDP-Malawi trilateral project on disaster risk management fall into this category. The second-generation projects are entirely funded by a third developed country. China provides technical experts and know-how, while the UNDP manages the project. For example, the China-UNDP pilot projects on disaster risk management in Bangladesh and Nepal are fully funded by the UK's DFID. The government of Denmark funds the China-UNDP renewable energy trilateral projects in Ghana and Zambia, with approximately $\$ 5.3$ million. The third-generation trilateral projects are still being developed. Ideally, the UNDP will implement one component of a large Chinese aid project. In particular, the UNDP will focus on the soft areas of this project, such as capacity building and system strengthening. This trilateral arrangement aims to complement existing Chinese aid practice, which usually focuses on physical infrastructure, and to assist China in improving its aid delivery system.

\section{Official Position}

The Chinese government is taking a cautious and incremental approach towards trilateral aid cooperation. This follows China's tradition of testing new decisions on a small scale before expansion. For example, in the early 1980s, China first tested the SEZs in the four cities of Shenzhen, Zhuhai, Shantou and Xiamen before expanding them to other cities in China and, eventually, beyond China's borders to parts of Africa (Bräutigam \& Tang, 2011). China has handled trilateral aid cooperation in a similar manner. Presently, the Chinese government has shown interest in testing trilateral aid cooperation and has been open to proposals that traditional donor states and multilateral development agencies have offered. After several years' experimentation, China's MOFCOM is assessing the performance of this new modality.

Trilateral aid cooperation is still a supplementary pilot modality in China. China has not issued a clear policy or guiding document for trilateral aid cooperation. Each project is managed on a case-by-case basis. However, China's position on piloting this kind of aid project complies with the core of China's foreign aid policy since the 1950s: non-interference, respect

6 The UNDP has categorised the China-UNDP-Cambodia trilateral project on cassava into this first generation, though in reality, the project was mainly funded by China; the UNDP contributed expertise and management. 
for sovereign equality and mutual benefit (State Council, 2011d, 2014). ${ }^{7}$ The five principles identified by then Ambassador Liu Guijin in 2008 for China's participation in trilateral aid cooperation in Africa, the largest recipient of Chinese aid, remain instructive. This is the most detailed explanation available from China's official sources. Chinese officials and experts echoed these principles during my interviews.

First, respect for Africa. No cooperation should be conducted at the cost of sovereignty, interest or dignity of any African country. In particular, we should heed the opinions of the African side on whether or not and how to conduct such cooperation, instead of imposing our opinions on the African side. Second, be pragmatic. Attention should be paid in such cooperation to combine good practices of other parts of the world with specific conditions of Africa to serve the actual needs of African countries and avoid 'one-size-for-all' practices that are neither practical nor effective. Third, step by step. We should start with small and easily operable projects and learn from experience and constantly improve our work. It is important to remember 'More haste, less speed'. Fourth, everyone doing his best. The key to success of the triangular cooperation is to let each party do what it is best at. When developed countries are involved in the triangular cooperation, their financial strength should be combined with developing countries' advantages in applicable technologies and cost. Fifth, efficiency. The triangular cooperation should make full use of existing authoritative cooperative mechanisms, such as the United Nations development assistance mechanism, to avoid overlapping institutions and waste of resources caused by setting up too many new mechanisms. (Liu, 2008, pp. 5-6)

Chinese officials have repeated these principles on other occasions, though briefly. For example, the China-US MOU on development cooperation, signed in September 2015, stated clearly that 'the principle of raised, agreed and led by recipient countries is a prerequisite for all

$7 \quad$ The three principles are also reflected in the eight principles for China's aid to other countries that were suggested by Premier Zhou Enlai during his visit to Africa in 1964. The eight principles include 1) China always bases itself on the principle of equality and mutual benefit in providing aid to other nations; 2) China never attaches any conditions or asks for any privileges; 3) China helps lighten the burden of recipient countries as much as possible; 4) China aims to help recipient countries gradually achieve self-reliance and independent development; 5) China strives to develop aid projects that require less investment but that yield quicker results; 6) China provides the best-quality equipment and materials of its own manufacture; 7) in providing technical assistance, China shall confirm that the personnel of the recipient country fully master such techniques; and 8) the Chinese experts are not allowed to make any special demands or to enjoy any special amenities. 
cooperation' and that the areas of cooperation must be 'in accordance with the principle of recipient country ownership' (USAID, 2015c, pp. 1-2). The eighth China-US S\&ED held in Beijing in June 2016 pledged that the two nations would promote trilateral aid cooperation under the principle that such cooperation is raised, agreed and led by recipient countries (US Department of State, 2016). The same principles were highlighted by China's Ambassador to South Africa Tian Xuejun on China-Western donors-Africa trilateral cooperation in November 2015, and by China's Assistant Foreign Minister Liu Haixing at the symposium on China-France-Africa trilateral cooperation held in Beijing in April 2016 (MFA, 2015e, 2016a).

\section{The Administration of China's Trilateral Aid: Bureaucratic Arrangements}

The Chinese government has committed high-level political support to existing trilateral projects. MOFCOM had dominated the approval process until the establishment of CIDCA in April 2018. Initiatives from traditional donor states and UN agencies for trilateral cooperation must go through MOFCOM for approval. MOFCOM had shown interest in conducting some selected trilateral projects without other agencies being involved, as is the case for the China-UNDP-Cambodia trilateral cassava project. Due to human and technical resource constraints, MOFCOM approved some trilateral initiatives, but invited line agencies in China to help progress them. One typical example is the China-Australia-PNG trilateral malaria control project. Although MOFCOM was involved in the negotiation and exploratory missions, China's National Health Commission is undertaking the technical work, including the selection and dispatch of Chinese medical experts.

Within MOFCOM, both the DITEA and the DFA had been involved in managing China's trilateral aid cooperation. In terms of human resources, the involvement of DITEA in China's trilateral cooperation is understandable, though its primary responsibility is to oversee foreign aid to China. This business of managing foreign aid to China has dwindled, as traditional donors have either phased out or reduced their aid programs in China. As such, DITEA has an incentive to take over some trilateral projects as a new area of business, as the reduction of incoming aid has left it with a surplus of staff and resources. In contrast, the DFA is severely understaffed and overwhelmed by the skyrocketing business of providing 
bilateral aid overseas. This greatly limits its appetite for initiating or managing trilateral cooperation. A MOFCOM aid official explained that DFA officials could hardly finish their daily work on China's aid projects overseas, let alone spare any energy to work on trilateral projects (Interview with Chinese aid official, Beijing, 4 August 2015). Under such circumstances, the DFA welcomes the involvement of DITEA in trilateral aid cooperation, while trilateral projects potentially give DITEA a new lease on life against a background of declining aid to China.

However, in terms of financial resources, the DFA still receives an annual allocation of foreign aid funding from China's MoF, while DITEA does not. For example, the China-UNDP-Cambodia trilateral cassava project was funded by the DFA. In this sense, the DFA 'has to' get involved in China's trilateral aid projects. Additionally, being the department tasked to oversee Chinese foreign aid, the DFA must be involved in the trilateral aid projects and ensure that they run well.

Consequently, both DITEA and DFA had been involved in Chinese trilateral aid cooperation. It is not surprising that DITEA officials sometimes attended the opening ceremony of a trilateral project, while DFA officials were involved in the inspection process. It is easier for DITEA and DFA to negotiate and divide the labour among themselves, as they answer to the same ministry (Interview with MOFCOM former senior aid official, Beijing, 1 September 2015). The China-UNDPCambodia trilateral project on cassava, as examined in Chapter 4, is a case in point. Both departments were involved in the project to some extent. The opening ceremony of the first phase in Hainan was addressed by Deputy Division Director Cai Fang from the DFA. The conclusion ceremony of the first phase was officiated by Deputy Director-General Zhu Hong from DITEA. Division Director Liang Hong from DITEA headed the joint monitoring and reviewing mission of the second phase.

\section{Assessment of Trilateral Cooperation}

The future of trilateral aid cooperation depends on whether positive experiences can be drawn from the pilot projects for all three parties involved. The existing literature expects trilateral aid cooperation to bring in added value-including facilitating cognitive learning and experience sharing among different types of donors and recipient countries and amplifying aid cooperation while facing challenges such as 
increased coordination and higher transaction costs relative to bilateral aid. A question remains: how far are these anticipated advantages and challenges borne out by the experience of trilateral projects on the ground? Based on my extensive interviews with aid officials and participants in Chinese trilateral aid projects, the following trends can be discerned.

Trilateral aid cooperation provides more learning opportunities than bilateral engagement for beneficiaries in recipient countries. These beneficiaries are exposed to technologies and practices from both traditional and emerging donors. They have the luxury of comparing and contrasting and choosing the more suitable ones for themselves. For example, China and Australia have completed a trilateral project on irrigation dialogue in Cambodia. Three official trips were organised to observe the different agricultural irrigation policies and practices in the three countries between 2013 and 2014. Dr Sokhem Pech, the main initiator of the project from Cambodia, explained their needs for implementing this trilateral project:

We told them [partners from China and Australia] we want to know how you do water cooperatives, how you promote longterm sustainability [of irrigation], how you make sure you have water for farmers, and how you ensure you can collect fees for cost recovery and for long term sustainability financially and in terms of agricultural production. (Interview, Phnom Penh, 14 July 2015)

Dr Sokhem Pech seemed satisfied that these objectives appeared to have been achieved in this particular case. Sophak Seng, another main participant in the project from the Cambodia Irrigation Services Center, agreed with the evaluation (Interview, Phnom Penh, 10 July 2015).

Now, let us listen to the voices of four students from the National University of Timor-Leste. They participated in the China-US-TimorLeste trilateral agricultural project and experienced technical training on the cultivation of maize from China and on the cultivation of onion, beans and garlic from the US. Although complaining that Chinese experts only taught general knowledge in the classroom by lecturing and that they only included farmers (not students) in the field practices relative to their US peers, these students were overall satisfied with what they learned (Interview with the four students, Phnom Penh, 6 February 2015). They also expressed a strong interest in learning how the Chinese experts could harvest maize on land that locals deemed unsuitable for growing corn (Interview with the four students, Phnom Penh, 6 February 2015). 
In contrast to traditional donors, it must be asked: are the technologies from emerging donors more appropriate and acceptable to recipient countries than from traditional donors? Not necessarily. In addition to the potential advantage of combining the different strengths of traditional and emerging donors, the involvement of these different donors in a single aid project provides more options for recipient countries and exposes them to different practices. As China's trilateral aid cooperation is in its infancy, it will take some time for the beneficiaries in recipient countries to understand this new modality and then judge which technologies are more suitable for them (from China or traditional donors).

Some argue that linguistic and cultural similarities between emerging donors and recipient countries are advantageous for the involvement of emerging donors, but this is not inevitably the case. A study of German trilateral aid cooperation argued that linguistic and cultural similarities between emerging donors and recipient countries do not necessarily favour effectiveness (Lengfelder, 2015, pp. 7-9). One policy advisor from the German Ministry of Economic Cooperation and Development noted that some aid officials from emerging donors are drawn from the elite in their countries and have little firsthand experience with poverty and development (Lengfelder, 2015, p. 8). Further, it is natural for people to question the relevance of China's approaches in the context of Africa and the Pacific, where presumably cultural and linguistic similarities are lacking.

In terms of assessment, although Germany has been among the earliest pioneers in practising trilateral aid cooperation, German policymakers repeatedly suggest that it is still new and difficult to assess the effectiveness (Lengfelder, 2015, p. 8). Turning to China's trilateral cooperation, the differences between China and recipient countries such as PNG, TimorLeste and Cambodia are substantial in terms of linguistics and cultures. Consequently, the workload of project preparation and management has increased.

Transaction cost is another contentious issue for trilateral projects. Trilateral aid cooperation involves additional donor engagement/input relative to bilateral aid. There are also considerable differences between traditional and emerging donors, ranging from guiding aid principles to practices on the ground. The complexity is reinforced by organisational culture and language differences in many occasions. These factors naturally lead to increased costs of coordination and negotiation for trilateral 
projects, as well as greater scrutiny in their home countries. Aid officials and researchers from both donor and recipient countries frequently mentioned the issue of additional costs.

Take the China-Australia-PNG trilateral malaria project as a typical example. The three countries began preparing and discussing the project shortly after the signing of the China-Australia MOU on development cooperation in April 2013. However, more than two years passed before the three sides finally signed the project agreement in October 2015. A senior Australian aid official commented on this, and his statement included the response from his counterpart in China's MOFCOM. These remarks are illustrative of Australian and Chinese perceptions regarding the issue of transaction costs:

This malaria project is our first formal thing to have engagement [with China on development cooperation]. Even this project has taken a long time, much longer than it would take for such a small project. This project is 4 million Australia dollars in value. Compared with the Australia aid in PNG about half a billion per year, it is tiny. It has taken over a year, from October 2013 [the formal discussion between China and a visiting Australian and PNG delegation] to October 2014 [the project was agreed in principle]. This is a tiny project, but it takes a long time. But it is understandable. Mr Zhang, the division director from MOFCOM is quite open to this trilateral malaria project. He said, for China, this is a new thing. So, it takes a long time, and they are even very careful about wording. This is already quite quick [for China]. (Interview, Port Moresby, 4 November 2014)

Another senior Australian aid official expressed similar views:

For the Australia-China-PNG trilateral malaria project, though the project volume is not big, the negotiation and coordination cost is huge. The project [was] supposed to start in early 2015, but it has not started yet. It is almost closer to the starting point. The three sides will finally sign the project agreement. The slow progress is not because either side intentionally delays the progress, but because trilateral cooperation is a new modality, and it takes time for the three countries to coordinate. (Interview, Beijing, 4 August 2015) 
Some Chinese aid officials share these concerns. A Chinese aid official commented on the transaction cost of the China-UK (together with the UNDP) trilateral aid project on disaster relief management in Bangladesh and Nepal, linking it to the understaffing problem with China's ministries.

For China's Ministry of Civil Affairs (MCA, main participant from China), they do not have much knowledge of the UK's Department for International Development (DFID). They hope to increase the understanding of DFID through the conduction of the trilateral project. But in practice, the challenge of coordination is daunting. For instance, The MCA's division that was involved in the project only has three staff including the division director. What makes the issue worse is that only the division director can speak English. He had to attend all the coordination meetings with DFID by himself. As he has a lot of other work to do every day, how can he spend that sort of time attending DFID's meetings? That's why MCA itself did not want to get involved, and designated the project to its affiliate, the China National Disaster Reduction Centre. (Interview, Beijing, 4 August 2015)

However, some aid practitioners have expressed different views regarding the transaction costs of trilateral cooperation. A major participant from Australia in the China-Australia-Cambodia triangular project on irrigation dialogue argued that triangular cooperation does not have to be more time consuming than any other multi-actor aid activity (Interview, Phnom Penh, 20 July 2015).

As China is emphasising its global image-building more and learning from traditional donors to improve its own aid practices, trilateral aid cooperation would be expected to grow slowly in China's foreign aid program. However, this should not be taken as given. Aid officials from both China and traditional donor nations repeatedly reminded me that they are closely following the progress of pilot projects. If these projects are perceived as-or reported to be-a success, this could lead to future cooperation. In the absence of positive results, it is likely that China and traditional donors would withhold and perhaps end the experiment. For example, Chinese officials told Australian aid officials that China would not consider anything else, whether in PNG or elsewhere, unless they observe how this malaria project proceeds (Interview with senior Australian aid official, Port Moresby, 4 November 2014). A senior New Zealand aid official said that: 
$\mathrm{NZ}$ is focusing on the current trilateral water project [in Cook Islands], to see how it progresses. NZ is open to other triangular cooperation opportunities with China, but will not push for them. (Interview, Wellington, 10 December 2014)

Merriden Varrall, a former UNDP senior representative in Beijing, argued that China's Minister of Commerce, Gao Hucheng, who took up his post in March 2013, has 'preferred a more cautious approach to trilateral cooperation, and wanted to see evidence of success with the existing projects before approving new initiatives' (Varrall, 2016, p. 28). According to Varrall, Minister Gao's conservative and risk-averse manner meant that MOFCOM's enthusiasm for trilateral aid cooperation 'distinctly waned', especially towards cooperation with traditional donor states (Varrall, 2016, p. 28). However, some UNDP officials have argued recently that MOFCOM, especially the DFA, has become more active in exploring trilateral aid cooperation with the UNDP since late 2015 to materialise the south-south cooperation fund that President Xi pledged at the UN summit in September of the year (Interview, Canberra, 29 June 2016).

The Chinese government is still assessing the effectiveness of its pilot trilateral aid projects. Its attitude towards future cooperation is not yet fully formed and some confusion and uncertainty remains. A senior Chinese aid official told me that China intended to learn more from the traditional donors' aid practices, but that MOFCOM doubted whether this can actually be achieved because its involvement in the process of trilateral aid projects is so limited (Interview, Beijing, 4 August 2015). Although China and traditional donors have started pilot trilateral projects, substantial differences between their aid policies remain and further engagement to boost understanding is expected from both sides.

Moreover, China and traditional donors are still confining their trilateral cooperation to less sensitive areas, such as agriculture, public health, food security and technical training. These areas are more acceptable to the Chinese side and render cooperation more feasible. For example, health appears to be a potential area for China-US trilateral aid cooperation, including in Africa. Scholars from China and the US, such as Deborah Bräutigam and vice president of the China Institute of International Studies Liu Youfa proposed that the two superpowers could cooperate in this area (Freeman III \& Lu Boynton, 2011, pp. 11, 15). David H. Shinn argued that cooperation in Africa's health sector is less likely to 
cause political conditionalities from the US and therefore it will avoid potential objections from African countries (Shinn, 2011). Trilateral cooperation beyond these areas could be difficult to initiate at this stage. Equally important is how China has repeatedly conveyed the message to traditional donors that recipient countries' support is a precondition for its endorsement of trilateral cooperation. If recipient countries initiate and propose trilateral projects to China, then China will more likely approve them. Some officials from recipient countries have already complained that they were not consulted adequately in regard to, for example, the European Union's plan for trilateral cooperation in Africa (Wikileaks, 2010).

As China is familiarising itself with trilateral aid cooperation through the pilot projects, it is quite possible that China will continue to experiment with the current crop of 'familiar' traditional donor states and multilateral development agencies. It is likely that they will expand trilateral cooperation into more areas and with more donors. For example, building on their recent trilateral cooperation on agriculture in Timor-Leste and the joint training of Afghan diplomats, armies from China and the US conducted the disaster management exchange program in November 2015, which USAID said could 'advance coordination in humanitarian disasters taking place in a third country' (USAID, 2015e, p. 4).

Trilateral aid cooperation between China and the UNDP is expected to grow, as the two sides have shown interest in testing different types of trilateral cooperation and in expanding this modality. Similarly, China-UK trilateral cooperation is also expected to grow. As early as 2006, the UK's DFID launched a formal dialogue with China regarding development cooperation. The UK Parliament endorsed this engagement, believing that it was embedded within the UK's wider strategy for China: 'Getting the best for the UK from China's rise; fostering China's emergence as a responsible global player; and promoting sustainable development, modernisation and internal reform in China' (UK Parliament, 2009, p. 36). In October 2010, UK International Development Secretary Andrew Mitchell told the media that 'we are looking to work very closely with China' as a high priority for the UK government because this will enable the UK to 'do much more to speed up development in Africa' (Hawksley, 2010). A more recent development of China's trilateral cooperation relationships is that China and France are exploring 
opportunities for trilateral aid cooperation-and one such symposium was held in Beijing in April 2016. China's Assistant Foreign Minister Liu Haixing highlighted at the conference:

To carry out trilateral cooperation between China, France and African countries conforms to the trend that nations promote cooperation of mutual benefits and strengthen interest integration to realise common development in the context of economic globalisation. (MFA, 2016a, para. 2)

It is likely that China will partner with more traditional donors in the future.

In terms of recipient countries, their initial request for such assistance will be a critical factor for China in determining whether it delivers aid bilaterally or trilaterally. It can be expected that China will do more trilateral aid cooperation in recipient countries who are struggling with aid coordination and who express a desire to boost aid coordination between China and traditional donors. Recipient countries that perceive more advantages in using Chinese aid to increase their leverage with traditional donors will prefer to receive bilateral aid from China rather than support trilateral cooperation. China is unlikely to undertake trilateral projects in these countries. This explains why a senior Chinese aid scholar commented that 'China will not conduct trilateral aid cooperation for the sake of cooperation itself if it comes at the expense of its relations with other developing countries' (Interview, Beijing, 30 August 2015). A possible method for identifying trilateral aid cooperation is by identifying recipient countries who have interests in this kind of cooperation. David H. Shinn suggested that the US and China will identify countries like Liberia, who seem to welcome trilateral cooperation, and focus on them (Shinn, 2011).

\section{Chinese Aid Reform and the New Aid Agency}

Trilateral aid cooperation is just one manifestation of Chinese foreign aid reform. To some extent, the future of Chinese trilateral cooperation also depends on the Chinese government's continued willingness to pursue aid reform. Therefore, it is worth elaborating on recent trends in Chinese aid reform. 
In the short term, it is most likely that China will continue increasing foreign aid for the benefit of its economic, political and global-image interests. China is likely to align its aid program with recently announced initiatives, such as the AIIB, the BRI and the BRICS New Development Bank. It is also expected to link its foreign aid to the implementation of SDGs in developing countries.

China's poverty reduction at home and foreign aid provision are interrelated, despite being two seemingly different themes. China's own experience in eradicating poverty can be shared with other developing countries, though to what extent it can work in culturally diverse settings is debatable. Additionally, the international acknowledgement of China's efforts to reduce poverty at home and abroad is deemed conducive by the Chinese government to its global image-building, and it has strengthened its interests in development assistance. As a senior Chinese scholar who preferred to remain anonymous revealed:

Chinese President Xi Jinping was credited for China’s incredible contribution to achieving the Millennium Development Goals during the 2015 UN Summit [he was quite happy with this], which in turn reinforced China's commitment to poverty reduction at home and abroad. (Conversation with Chinese scholar, Canberra, February 2016)

This can be demonstrated by the convening of two of the highest-level conferences soon after President Xi's trip to the UN. On 23 November 2015, the political bureau of the CPC's central committee-the top decision-making organ in China-held a special conference on poverty reduction, a rare engagement with this issue at such a high level in China. The conference issued the 'Decision on Winning the Tough Battle on Poverty Reduction ${ }^{8}$ and also pledged to implement strict accountability for government officials (Xinhua, 2015c). In less than one week, the national conference on poverty reduction was held in Beijing and it was attended by all seven members of the standing committee of the CPC political bureau, as well as governors from all the provinces. President $\mathrm{Xi}$ instructed government officials at all levels to 'carry out more targeted and precise measures' to lift the remaining 70 million poor people out of poverty by 2020' (Xinhua, 2015a, para. 1 ).

8 President Xi's new approach to poverty alleviation — such as targeting the individual, employing the whole of government (not just the poverty alleviation bureau) and using many military metaphorsdoes mark a break with previous approaches, which targeted poverty counties and later villages. 
On 15 December 2015, the China State Council held a news briefing on poverty reduction at China's 13th five-year plan. Liu Yongfu, director of the China State Council Leading Group Office of Poverty Alleviation and Development, responded to a question raised by Reuters regarding why China is providing foreign aid while it has more than 70 million people living in poverty. As a main decision-maker for China's poverty reduction ${ }^{9}$ and international exchange on poverty reduction, his answer sheds some insight on understanding China's motivations behind aid:

China is a developing country and also a responsible great power ... While doing our own things well, we are supporting other [developing] countries by sharing our experiences even piloting poverty reduction within our capacity. We believe it is the right thing to do as we are a permanent member of the UN Security Council, the second largest economy in the world and a responsible great power. (State Council, 2015, para. 35)

It can also be said that China will not embrace all Western aid norms and abandon its own. The main reason why is that China will still hold tightly to its identity as a developing country, from which it has reaped and will continue to reap tremendous benefits. This identity will help China lobby for support from other developing countries, including at the UN, when disputes arise between China and the developed countries. Consequently, it is least likely that China will join the OECD in the short term, even though it is now the second-largest economy. Ye Jiang, director of the Institute for Global Governance Studies from Shanghai Institutes for International Studies, said that:

China can play a role as a bridge between the South and the North, but will not become a member of OECD as the rich's club. China still sticks to the principle of 'common but differentiated responsibilities' in development cooperation. China will never commit to DAC's 0.7 per cent GNI target, as there is still a big poor population at home. ${ }^{10}$

9 Although China's poverty reduction at home and its foreign aid delivery are two separate issues, they are related to some extent. Many of China's foreign aid projects have roots in its poverty reduction at home. For example, China's emphasis on aiding infrastructure projects in recipient countries is derived from its experience of economic development at home.

10 Presentation at the 2016 Australasian aid conference at ANU, 10 February 2016. 
In recent years, the OECD has strengthened efforts to engage with China, such as by establishing the China-DAC study group and providing training for Chinese officials, as discussed in Chapter 3. This engagement is paying off for the OECD, as China has demonstrated more readiness to cooperate with the OECD. In July 2015, China's Premier Li Keqiang became the first Chinese leader to visit OECD headquarters in Paris. During the visit, China agreed to join the OECD development centre, which represents itself as a platform for finding solutions to stimulate growth in developing countries, and pledged to 'share the development experience with other members of the OECD Development Centre and promote global economic growth' (B. Chen, 2015). OECD SecretaryGeneral Angel Gurría credited this agreement as 'a historical and transformative opportunity for mutually beneficial knowledge-sharing [between China, OECD, and other developing countries]' (OECD, 2015b). China has also agreed to accept the OECD policy coherence for sustainable development, a policy tool used to integrate the various dimensions of sustainable development into policymaking and to ensure that they are mutually supportive (OECD, 2015a, p. 24). This can potentially improve the development coordination between China and OECD members in other developing countries.

Though encouraging, over-interpretation of China's membership must be avoided. In addition to 26 members of developed countries, another 22 developing countries (including India and Brazil) joined the OECD development centre prior to China. As a senior Chinese aid official reminded me, the OECD development centre is totally different from the OECD because the task of the former is centred on development research, much of which focuses on developing countries (Interview, Beijing, 4 August 2015). Moreover, as a senior Chinese scholar revealed, although the OECD sent an invitation to President Xi Jinping to visit its Paris headquarters during his visit to France in May 2015, China wanted to refrain from being too close to the OECD; therefore, it was Premier Li who visited OECD as a compromise. While significant, China sent its premier rather than its president, thereby signalling that this relationship did not yet merit a visit from the country's most senior leader (Conversation, Canberra, February 2016). A former senior Chinese aid official noted that China would not consider joining OECD DAC in the short term (Interview, Beijing, 1 September 2015). 
The OECD case also indicated that neoliberalism theories, as mentioned in Chapter 2, are insufficient in explaining China's endorsement for trilateral aid cooperation. These theories tend to focus on the roles of international institutions in promoting cooperation among member states. However, China is still cautious about its engagement with the OECD. It has consciously kept its distance from this organisation. By staying out of OECD DAC, China is not bound by their regulations on aid delivery. Put another way, China's adoption of trilateral partnership in aid delivery is not a result of international institutions such as OECD DAC.

\section{China International Development Cooperation Agency}

It is useful to reflect on the establishment of CIDCA due to the move in many parts of the OECD—such as Australia, Canada and New Zealand - to discard separate aid agencies and integrate them with their foreign affairs' ministries. For example, the Abbott government integrated AusAID into DFAT in September 2013 and announced a new aid paradigm that is actually the old paradigm reincarnate with incremental changes, such as the alteration to the geographical aid focus (Corbett \& Dinnen, 2015).

Chinese aid officials and analysts acknowledge the complexity and inadequacies of the Chinese aid management system. Xu Weizhong, director of the African Research Institute of China Institute of Contemporary International Relations and his colleague Wang Lei have argued that 'the fragmentation of aid funding and management has greatly compromised the efficiency of China's current inter-ministerial aid coordination system' (Xu \& Wang, 2015). They strongly recommend that China establish a separate aid agency. A senior Chinese aid scholar revealed that MOFCOM's DFA also supported the creation of a 'China aid agency' because China's officials are overwhelmed by their current workload (Interview, Beijing, 30 August 2015). She also mentioned that some officials from the China Exim Bank also supported integrating the fragmented Chinese aid agencies into a 'China aid agency', as well as including the concessional loans under this new agency (Interview, Beijing, 30 August 2015). Professor He Wenping from CASS supported the idea of creating a 'China aid agency' because 'as Chinese foreign aid is growing fast, it means you are growing up, you are not able to put on the kid's clothes as you did before' (Interview, Beijing, 28 July 2015). 
Amid these anticipations in March 2018, the China State Council announced the plan to establish an independent aid agency, CIDCA. In April, the vice ministerial-level CIDCA was officially launched in Beijing. Its main responsibilities are to strengthen Chinese aid planning, coordination and monitoring, and to fully support the BRI. Aid implementation is still the responsibility of existing aid agencies, including MOFCOM's three affiliates and the line ministries. After about six months' preparation, CIDCA started to function in late 2018.

The formation of CIDCA's senior management team provides a lens through which to understand the shift of power among China's ministries in aid management. Wang Xiaotao, a former deputy director of the China National Reform and Development Commission, became CIDCA's first director. This appointment, to the surprise of many analysts and even some officials from MOFCOM, can largely be interpreted as a compromise for MOFCOM and MFA, the two most important players in Chinese aid decision-making. As the China National Reform and Development Commission is the ministry that coordinates the BRI, Wang's appointment also reflects the Chinese government's desire to use aid to support the initiative-which is a signature project of President Xi Jinping. The first highest-ranking deputy director, Zhang Maoyu, worked in China's National Intellectual Property Administration for decades and had no experience with foreign aid, rendering his appointment surprising to many aid observers. The second highest-ranking deputy director, Zhou Liujun, was a former director-general of MOFCOM's Department of Trade in services and commercial services and of the Department of Outward Investment and Economic Cooperation. The third highest-ranking deputy director, Deng Qingbo, was previously China's ambassador in Dominica and Nigeria, as well as director-general of the MFA's Department of Party Related Affairs. The appointments of Zhou and Deng are telling signs that MOFCOM and MFA will continue playing significant roles in Chinese foreign aid.

In terms of reporting line, CIDCA will report directly to the State Council. To be more specific, it is under the supervision of State Councillor and MFA Minister Wang Yi. This is a strong signal that the MFA has power in the Chinese new aid system. Diplomacy will play a more prominent role in deciding Chinese aid spending. As the former custodian of Chinese aid, MOFCOM's role is weakened. However, it will continue to significantly influence, as the whole DFA has been relocated to CIDCA and now it forms most of the aid officials there. 
Being a new organisation, CIDCA's influence on China's trilateral aid cooperation is yet to be observed. Its structural arrangement on trilateral cooperation is also unclear. However, as previously discussed, both MFA and MOFCOM (MOFCOM to a lesser extent) are supportive of piloting trilateral aid cooperation. It is expected that CIDCA will continue to test this modality with traditional donor states and UN agencies.

\section{Some Thorny Issues}

As China increases its foreign aid spending, it has paid more attention to the quality and effect of its aid. The Chinese government has become more conscious of the weaknesses in its aid delivery and has started to take remedial measures.

Infrastructure is a main area of concern. Li Xiaoyun and Wu Jin from the China Agricultural University argued in 2009 that 'the West's criticism on this issue [China's overemphasis on infrastructure projects] is reasonable to a great extent. China should pay attention to this issue in its aid to Africa' (Li \& Wu, 2009, p. 53). However, despite the criticism, infrastructure is most likely to continue being the focus of Chinese aid. One reason is that China has a comparative advantage in this field in terms of cost and speed. Infrastructure projects are often large in scale and provide opportunities for China to export its equipment, building materials and workforce. Additionally, new initiatives such as the BRI, AIIB and the BRICS New Development Bank concentrate on supporting infrastructure construction in developing countries. A large proportion of Chinese foreign aid will be used to complement and support these new initiatives.

Another reason relates to the philosophy of the Chinese government, which originated in China's own development experience. The Chinese government regards infrastructure improvement as the first step for poverty reduction and economic development. It has formed an important component of China's own economic development plans. Even in the present day, building infrastructure remains a crucial tool for bolstering economic development in China's western regions. The proverb that 'to be rich you have to start by building a road' (yao zhi fu, xian xiu lu) has become embedded in the mindset of Chinese officials and civilians. This proverb is still daubed on the outside of many houses in rural China. As Wang Xiaoling, division director from the China International Poverty 
Reduction Centre, emphasised, one of the important lessons that China gained from its past experience of lifting approximately 600 million Chinese citizens out of poverty is its reliance on development-oriented poverty reduction (Wang, 2014).

However, while continuing to highlight infrastructure, the proportion of Chinese aid in welfare-related projects is expected to grow (e.g. agriculture, health, education and technical training). The Chinese government is increasingly conscious of the criticism regarding its overemphasis on infrastructure projects, and it is becoming more economically capable of spending a greater proportion of its aid budget on welfare-related projects. China will also explore new types of aid partnerships. For example, during President Xi's visit to the US in September 2015, Zhang Xiangchen, China International Trade representative deputy (vice ministerial level at MOFCOM) and Bill Gates signed an MOU on development cooperation. Based on this, the Chinese government and the Bill and Melinda Gates Foundation pledged to promote development cooperation in the areas of agriculture and health in Africa (Y. Chen, 2015). This sends a positive signal that China is more open to working with leading global private foundations on aid cooperation.

Similarly, China will pay more attention to the environmental and corporate social responsibility issues that surround Chinese companies in delivering their aid. David Dollar argued that 'China, in general, does not subscribe to global standards of environmental and social safeguards' (Dollar, 2016, p. 4). To urge Chinese companies to honour their social responsibilities overseas, several guideline documents have been jointly issued by MOFCOM and the Ministry of Environmental Protection, including the 2013 guidelines for environmental protection for overseas investment and cooperation, as mentioned in Chapter 3. Though this guideline is not binding, companies breaching environmental protection laws in recipient countries will face penalties from their headquarters in China. More similar documents are likely to be issued. However, the 'principal-agent dilemma' will remain. While the Chinese government highlights its strategic and global image interest in providing foreign aid, the Chinese aid companies will continue prioritising their own economic benefits. Therefore, their short-term economic interests could have the upper hand in the competition against the long-term interests of the Chinese state in some occasions. Traditional donors face a similar issue in using private contractors to deliver their aid, in which 'boomerang aid' is 
common. ${ }^{11}$ For example, the Australian government has insisted that its aid program must be in line with Australian national interests, and many aid projects are awarded to Australian private contractors (Aidwatch, 2012). One difference is that it is not mandated that a certain percentage of Australian aid has to be spent on Australian materials and equipment, while in China's concessional loan projects, no less than 50 per cent of materials and equipment are required to be purchased from China.

\section{Will China Attend Donors' Roundtable?}

China has frequently been criticised for not attending donors' roundtable meetings on development cooperation in recipient countries. Uidon Chung, deputy country representative of the Korean International Cooperation Agency in Dili, said that he has never seen Chinese aid officials at such meetings. He joked that traditional donors were often overjoyed when he attended the roundtable meetings because they mistook him for a Chinese aid official (Interview, Dili, 28 January 2015). Based on my field work in PNG, Timor-Leste and Cambodia, traditional donors and many aid officials from the recipient countries resent that China seldom attends the donors' roundtable meetings. A senior Chinese aid official gave the following reasons for this state of affairs:

China does not often attend this sort of donors' coordination meeting because traditionally China has been cautious. Normally, China will respond by saying that these meetings are not led by recipient countries. If the meetings are indeed led by recipient countries, for instance many such meetings are hosted by the Ministry of Finance in African countries, in general China will turn up, no matter whether it will speak or not. If the meetings are not led by recipient countries, China will not attend in most circumstances. This is because China normally will 'draw the line' believing it and developed countries belong to different camps. In addition, Chinese Economic and Commercial Counsellor's offices in many countries are under-staffed. Individual officials from these offices often have varying attitudes towards this sort of donors' coordination meetings. This will also affect whether they will attend or not. (Interview, Beijing, 4 August 2015)

11 Many analysts have complained that much of traditional donors' aid that is pledged to their countries has returned to the donors through means such as awarding the contracts to companies from donor states and paying the salaries for consultants from these countries. 
The capacity of recipient governments to manage aid coordination will influence China's attendance at such roundtable meetings. When they push hard, it is more likely that the economic and commercial counsellor's office in China's embassy will send staff to attend these meetings, though how active they will be at the meetings is another question. This concurs with the findings of Matthew Dornan and Philippa Brant, who examined Chinese aid to Vanuatu, Tonga, Samoa and the Cook Islands, arguing that Chinese aid is better managed in recipient countries with better aid coordination systems, such as Samoa and the Cook Islands (Dornan $\&$ Brant, 2014). However, the push from recipient countries is not a guarantee that China's representatives will attend aid roundtables. Based on my observations from 2006 to 2008, staff from the Chinese economic and commercial counsellor's office in Tonga did not actively participate in aid coordination meetings that were hosted by other donors, or even by the Tongan MoF. One main reason was that this office was understaffed and that the only two officials were preoccupied with other work, such as trade and investment promotion and hosting visiting Chinese delegations. China rarely showed up, even in Samoa, where the MoF led the aid coordination meetings, and if they did show up, they would often be late.

\section{Conclusion}

To summarise, this chapter extends from the analysis in the previous three chapters. An overview of China's trilateral partnership-including the main features, China's official policy and bureaucratic arrangement-is examined. It demonstrates that China regards trilateral aid cooperation as something new and that it is expanding the test with caution. China, together with traditional donors, is closely following the progress of the pilot projects.

As trilateral aid cooperation is a component of China's foreign aid reform, this chapter has also discussed some aspects of this reform process, particularly the newly established CIDCA. It argues that China would continue to pilot trilateral aid cooperation. There is also much room for China to increase its participation in the donors' roundtable meetings in recipient countries. 
This text is taken from A Cautious New Approach: China's Growing Trilateral Aid Cooperation, by Denghua Zhang, published 2020 by ANU Press, The Australian National University, Canberra, Australia.

doi.org/10.22459/CNA.2020.07 